\author{
Omirbekova N.Zh., Zhussupova A.I., Zhunusbayeva Zh.K., \\ Deryabina N.D., Askanbayeva B.N., Egiztayeva B.T. \\ Department of Molecular Biology and Genetics, \\ Al-Farabi Kazakh National University, Almaty, 050038, Kazakhstan \\ *e-mail: aizhan.zhusupova@gmail.com
}

\title{
Brachypodium distachyon as a model plant in wheat rust research
}

\begin{abstract}
All countries share the need to increase wheat yield and tolerance to adverse environmental factors. Rust, the most common infector of wheat, is widely dispersed on the territory of Commonwealth of Independent States (CIS). The data shows that on the territory of following countries: Kazakhstan, Kyrgyzstan, Russia, Belarus, Uzbekistan the percentage of infected wheat with rust from the total amount is approximately 20-25\% annually. Brachypodium distachyon can be regarded as a perspective model to study various mechanisms of a rust infection.
\end{abstract}

Key words: rust infection, Brachypodium distachyon.

\section{Introduction}

Wheat was one of the first domesticated food crops and for 8,000 years has been the basic staple food of the major civilizations of Europe, West Asia and North Africa. Today, wheat is the most widely grown crop in the world and provides $20 \%$ of the daily protein and of the food calories for 4.5 billion people. It is the second most important food crop in the developing world after rice. In recent years, wheat production levels have not satisfied demand, triggering price instability and hunger riots. It is the best of the cereal foods and provides more nourishment for humans than any other food source, being a major diet component because of the wheat plant's agronomic adaptability, ease of grain storage and converting grain into flour. Wheat is also a popular source of animal feed, particularly in years where harvests are adversely affected by rain and significant quantities of the grain are made unsuitable for food use. Such low-grade grain is often used by industry to make adhesives, paper additives, and several other products and even in the production of alcohol. With a predicted world population of 9.0 billion in 2050 , the demand for wheat is expected to increase by $60 \%$.

To meet this demand, annual wheat yield increases must rise from the current level of below $1 \%$ to at least $1.6 \%$. All countries share the need to increase wheat yield, tolerance to abiotic stresses, pathogens and pests, as well as to improve input use efficiency for a more sustainable wheat production. Improved agronomic practices and development of innovative cropping systems are also a priority aiming at rein- forcing synergies between national and international research programmes to increase food security, nutritional value and safety whilst taking into account societal demands for sustainable agricultural production [1].

Wings of Gold racers at The State Emblem of the Republic of Kazakhstan remind sheaves of grain, gold wheat, meaning labor, abundance and material prosperity [2]. Wheat is a very important annual or biannual grass from the genus Triticum with the high impact on the economics of the Republic of Kazakhstan, being one of the five leading world producers on the grain market due to the high quality of the processed grain. Apart from the traditional varieties of flour, special quality flours, customized to buyer requirements are also successfully exported, going in consent with the sectoral program of agro-industrial complex development for 2013-2020 «Agribusiness $-2020 »[3]$.

\section{Main part}

There are three types of rusts, which are infecting wheat in different ways: stem rust (Puccinia graminis), leaf rust (Puccinia recondita), and stripe rust (Puccinia striiformis). The symptoms are easy to detect. Firstly chlorotic flecks or brown necrotic spots appear on the leaves or stems, which further can develop into yellow strikes or patches on foliage. Another symptom of rust is brown necrotic streaks on foliage, but that occurs less rarely than the previous one. Sometimes upwardly raised orange pustules may be present on the lesions [4-6]. 
Puccinia is the fungus, which is hard to deal with. Emergence of the disease is especially sustained by wet and cool weather conditions. That means small wind or cold breeze even in sunny days can positively alter the propagation and development of that disease.

Rust, the most common infector of wheat, is widely dispersed on the territory of Commonwealth of Independent States (CIS). The data shows that on the territory of following countries: Kazakhstan, Kyrgyzstan, Russia, Belarus, Uzbekistan the percentage of infected wheat with rust from the total amount is approximately $20-25 \%$ annually.

According to the data of Kazakhstan Forbes division published at http://www.forbes.kz the worst condition of wheat in Kazakhstan was in 2007, when around $75 \%$ of all production was infected by rust. This year, according to experts in agricultural and economical sphere, the amount of infected wheat was about $22 \%$, what means that one fourth of all seeding has died without any use. In 2014 the total production of wheat collection was 17 billion tons, but if to take into account the wheat infected with rust, the amount of wheat could be 20.74 billion tons that year. The data is almost the same with 2015 year results.

1 ton of wheat costs $42,000 \mathrm{KZT}$ in 2015. 4 billion tons of infected wheat costs 168,000 billion tenge. That means that per year our country loses this amount of money because of the rust infection. That enormous amount of losses can be decreased by the proper investigating of the molecular mechanisms of that disease.

But the main issue is that the study of the rust disease on the wheat is very hard and complicated in the laboratory conditions. Wheat needs cool conditions of the environment; it has a slow generation cycle in comparison with other agricultural grasses. The question to find perspective and appropriate model organisms to study infectious diseases was unanswered for a long time. But the recent studies indicate that Brachypodium distachyon could serve as appropriate model organisms to study the molecular mechanisms of grass diseases' action [7, 8].

Nowadays the Brachypodium distachyon may also serve as a model organism here in Kazakhstan, because it has more advantages in comparison with studies based upon only wheat research. Brachypodium possesses characteristics required for an appropriate model to study cereal-pathogen interactions, including small stature, self-fertilization with the saved ability to cross-fertilize, rapid generation time, a compact genome and high transformation efficiency.
All those characteristics make Brachypodium distachyon very simple but effective model organism in studying the molecular mechanisms of infection. Its small stature and rapid generation time leads to the economy of territory, energy and nutrients required for optimal life establishment of a model grass. A compact genome and smaller amount of consequential repeats make the gene mapping and sequencing easier and faster, which is also important in data analysis of molecular action of infection inside the host's cell.

Brachypodium distachyon, like many grasses, is a host to rust pathogen described a little bit earlier in this article. That gives an another advantage of taking Brachypodium as a model grass, because through it all biological actions of host-cereal pathogen can be easily detected, observed and investigated much faster in comparison with studied based upon wheat [9-11].

Brachypodium distachyon is evolutionary very close to species like wheat, barley, oats, maize, rice, rye and sorghum. That quality of Brachypodium means that it can be very useful in fundamental genomics research of temperate grasses, and cereals. Those attributes also prove the statement written earlier about compact genome. Small genome of a Brachypodium distachyon is approximately 270 Mega base pairs. In addition only $21 \%$ of the Brachypodium genome consists of repetitive elements, in comparison with $26 \%$ in rice, and more than $80 \%$ in wheat (which is also a disadvantage of making a research based upon wheat molecular and genetic mechanisms). All genes are packed within five chromosomes, which make the genome very compact for a grass species. The complete genome of Brachypodium distachyon of inbred line $\mathrm{Bd} 21$ has been sequenced in Nature journal in 2010 [12].

Diploid and polyploid accessions make those perspective model organisms convenient to cultivate in a small place like laboratory. For early-flowering accessions it can take as little as three weeks from germination to flower (under an appropriate inductive photoperiod established in lad conditions). Brachypodium distachyon's small size is about 15-20 $\mathrm{cm}$ long, which is tightly connected with rapid generation cycle of eight to twelve weeks. As a weed, it does not require specialized growing conditions, and is able to grow in temperate environmental conditions.

Brachypodium is considered to be a non-host to infection caused by rust. That means that Brachypodium has the ability to be resistant to all races, variants, and subtypes of the rust infections. Nowadays, 
scientists know a few about the non-host molecular mechanisms in grass species. However, the infection of Brachypodium accessions with P. striiformis $\mathrm{f}$. $\mathrm{sp}$. tritici, hordei and bromi (wheat, barley and brome stripe rust, respectively) resulted in symptoms on different accessions ranging from the formation of small sporulating uredinia, to macroscopic lesion formation, to apparent immunity [13-15].

After the infection the microscopic analysis of stripe, stem, and leaf rusts showed no macroscopically visible lesions. But the source of these lesions identified a distribution of infection sites which contain hyphae within the grass apoplast and haustoria formation within the plant mesophyll cells. Brachypodium lines with macroscopically visible lesions and/or pustule development when infected by cereal rust pathogens showed extensive underlying fungal colonization of plant mesophyll cells with frequent haustoria formation at these sites.

It has also been shown that cell death is not in common within the infection sites, despite the extensive or fungal colonization. Also, Brachypodium callose deposition sites were proven to be identical to the callose deposition sites in wheat species during the basal immune response against these same rust pathogens. In both plant species, larger rust infection sites were proven to be able to suppress callose production in weak or old cells, supporting the theory of the presence of mechanistic overlap between the Brachypodium response to cereal rust infection and the wheat basal defence response. The data also shows the absence of change in salicylic acid level in Brachypodium leaf upon artificial infection with Puccinia subtypes [16-18].

Subsequent genetic analysis of Brachypodium distachyon rust infection has indicated that segregation between extensive and restricted wheat stripe is always inherited throughout the generations. The inheritance is controlled by a single dominant gene, which means that the positional cloning of those responsible genes for different phenotypic characteristics could be the real help in investigating the molecular mechanisms of rust infections behind non-host resistance in grass species [19-21].

All those features of Brachypodium distachyon makes it a perspective model to study the mechanisms of tolerance to rust infection. And it is currently being studied by our working group in terms of nitrogen and energy metabolism changes in control and test plants; results published locally and abroad (Kazakhstan, Italy, Spain, France).

\section{References}

1. Wheat initiative: coordinating global research for wheat. Available at: www.wheatinitiative.org.

2. National symbols of the Republic of Kazakhstan. Available at: www.egov.kz/wps/portal/Content? contentPath=/egovcontent/state symbols\&lang=en

3. Government approvedAgribusiness-2020 Program (from February 12, 2013). Available at: www. primeminister.kz/news/show/29/v-pravitelstve-prinjali-programmu-razvitija-apk-\% $\% 2 \% \mathrm{ABagrobiznes-}$ $2020 \% \mathrm{C} 2 \% \mathrm{BB} / 12-02-2013$ ?lang=en

4. Sinclair W.A., Lyon H.H. Diseases of trees and shrubs. 2nd ed. Ithaca, NY: Cornell University Press, 2005. -659 p.

5. Peterson P.D. Stem rust of wheat: from ancient enemy to modern foe. US: APS Press, 2001. -168 p.

6. USDA-ARS Cereal Disease Laboratory Update. Available at: http://www.ars.usda.gov/main/ site main. htm? modecode $=36-40-05-00$

7. Li C., Rudi H., Stockinger E., Cheng H., Cao M. et al. Comparative analyses reveal potential uses of Brachypodium distachyon as a model for cold stress responses in temperate grasses // BMC Plant Biol., 2012. - Vol. 12. - P. 65.

8. Li C., Rudi H., Stockinger J. et al. Comparative analyses reveal potential uses of Brachypodium distachyon as a model for cold stress responses in temperate grasses. Strong population structure characterizes weediness gene evolution in the invasive grass Brachypodium distachyon // Molecular Ecology, 2009. - Vol. 18. - P. 2588-2601.

9. Girin T., David L., Chardin C., Sibout R. et al. Brachypodium: a promising hub between model species and cereals // Journal of Experimental Botany, 2014. - Vol. 65. - No. 19. - P. 5683-5696.

10. Nirmala J., Drader T., Lawrence P.K., Yin C. et al. Concerted action of two avirulent spore effectors activates reaction to Puccinia graminis 1 (Rpg1)mediated cereal stem rust resistance // Proc. Natl. Acad. Sci. USA, 2011. - Vol. 108. - P. 14676-14681.

11. Figueroa M., Castell-Miller C.V., Li F., Hulbert S.H., Bradeen J.M. Pushing the boundaries of resistance: insights from Brachypodium-rust interactions // Frontiers in plant science, 2015. - Vol. 6. A. 558. - P. 1-11.

12. The International Brachypodium Initiative. Genome sequencing and analysis of the model grass Brachypodium distachyon // Nature, 2010. Vol. 463. - No. 7282. - P. 763-768. 
13. Bakker E.G., Montgomery B., Nguyen B., Eide K. et al. Strong population structure characterizes weediness gene evolution in the invasive grass Brachypodium distachyon // Molecular Ecology, 2009. - Vol. 18. - P. 2588-2601.

14. Vain P., Worland B., Thole V. et al. Agrobacterium-mediated transformation of the temperate grass Brachypodium distachyon (genotype $\mathrm{Bd} 21$ ) for T-DNA insertional mutagenesis» // Plant Biotechnology Journal, 2008. - Vol. 6. - No. 5. - P. 236-245.

15. Lee M.Y., Yan L., Gorter F.A. et al. Brachypodium distachyon line $\mathrm{Bd} 3-1$ resistance is elicited by the barley stripe mosaic virus triple gene block 1 movement protein // Journal of General Virology, 2012. - Vol. 93. - P. 2729-2739.

16. Thole V., Worland B., Wright J. et al. Distribution and characterization of more than 1000 T-DNA tags in the genome of Brachypodium distachyon community standard line Bd21, 2010 // Plant Biotechnology Journal. - Vol. 8. - No. 6. - P. 734-747.

17. Huo N., Vogel J., Lazo G. et al. Structural characterization of Brachypodium genome and its syntenic relationship with rice and wheat, 2009 // Plant Mol. Biol. - Vol. 70. - No. 1-2. - P. 47-61.

18. Goddard R., Peraldi A., Ridout C., Nicholson P. Enhanced disease resistance caused by BRI1 mutation is conserved between Brachypodium distachyon and barley (Hordeum vulgare) // Mol. Plant Microbe Interact. - Vol. 27. - No. 10. - P. 1095-1106.

19. Hasterock R., Marasek A., Donnison I. et al. Alignment of the genomes of Brachypodium distachyon and temperate cereals and grasses using bacterial artificial chromosomes landing with fluorescence in situ hybridisation // Genetics, 2006.

20. Wolny E., Hasterock R. Comparative cytogenetic analysis of the genomes of the model grass Brachypodium distachyon and its close relatives // Ann. Bot., 2009. - Vol. 104. - No. 5. - P. 873-881.

21. Gordon S., Priest H., des Marais D. et al. Genome diversity in Brachypodium distachyon: deep sequencing of highly diverse inbred lines // Plant J., 2014. - Vol. 79. - No. 3. - P. 361-374. 